\title{
A STUDY ON HIGH STRENGTH CONCRETE WITH MODERATE CEMENT CONTENT INCORPORATING LIMESTONE POWDER
}

\author{
ALAA M. RASHAD AND HOSAM.EL DIN H. SELEEM
}

\begin{abstract}
This paper presents the results of an investigation to assess the validity of producing high strength concrete (HSC) using moderate cement content to reduce the consumption of the binders. Cement content is lowered from $500 \mathrm{~kg} / \mathrm{m}^{3}$ to $400 \mathrm{~kg} / \mathrm{m}^{3}$. The difference in cement content is compensated by the addition of fine limestone (LS) powder. Pozzolans were incorporated as an addition to cement. Different coarse aggregate types were employed. Workability, compressive strength, tensile strength, permeability and drying shrinkage were measured. Test results revealed that HSC with a compressive strength up to 79 MPa (at 90 days age) could be produced with moderate cement content. The mixtures consistency and drying shrinkage are greatly enhanced due to employing LS powder and the permeability is satisfactory. To provide better solution to some concrete disadvantages like cracking and drying shrinkage, using an economic rate for cement are believed to reduce these disadvantages.
\end{abstract}

Keywords: high strength, cement content, pozzolan, limestone powder, concrete proportioning

\section{Introduction}

The definition of HSC has evolved with its gradual development and usage over the years. According to the latest achievements in concrete ingredients and the technology of production the following cement-based concrete classification is made (Kmita, 2000): (i) conventional concrete (CC), up to grade $60 \mathrm{MPa}$; (ii) high strength concrete (HSC), grades 60 - $90 \mathrm{MPa}$; (iii) very high strength concrete (VHSC), grades 90 - $130 \mathrm{MPa}$; (iv) reactive powder concrete (RPC), grades 200 - $800 \mathrm{MPa}$; (v) high performance lightweight concrete (HPLC) greater than $55 \mathrm{MPa}$. The notion of high performance concrete (HPC) was introduced to ensure the needs to other high parameters in certain civil engineering branches apart from its compressive strength.

There is a general agreement (Glaccio and Zerbino, 1998) about the importance of the matrix-aggregate bond. Thus, the type of coarse aggregate is one of the most important variables affecting the behaviour of HSC. It was generally concluded, that not all aggregate types are suitable as they may restrict the overall strength potential of the concrete due to the 'ceiling strength' of the material, which may break down before the cementitious matrix. From the theory of granular mechanics, Chang and Su (1996) showed that there is a good correlation between the compressive strength of aggregates and some of the engineering properties of concrete. For an optimum compressive strength with a high cement content and low w/b ratio, the maximum aggregate size should be kept to a minimum of $9.5 \mathrm{~mm}$ (ACI Committee 363, 2001). The effect of aggregate type and its maximum size on some properties of HSC, in the literature, can be summarized as following: Beshr et al. (2003) studied the effect of four types of coarse aggregates namely calcareous, dolomitic, quartzitic limestone and steel slag on the compressive and tensile strength of HSC. The results showed that the steel slag aggregate

Building Materials Research and Quality Control Institute, Housing \& Building National Research Center, HBRC, Cairo, Egypt, a.rashad@hbrc.edu.eg 
concrete gave the highest compressive strength, whilst calcareous limestone aggregate concrete gave the lowest compressive strength. Steel slag aggregate concrete gave also the highest tensile strength followed by dolomitic quartzitic limestone aggregate concretes. Kılıç et al. (2008) studied the influence of aggregate type on the strength characteristics and abrasion resistance of HSC. Five different aggregate types named gabbro, basalt, quartzite, limestone and sandstone were used to produce HSC containing silica fume (SF). Cement was partially replaced with $15 \%$ SF. The used w/b ratio was 0.35 . The amount of hyperplasticizer (carboxic type) was $4 \%$ of the binder content. The results showed that the gabbro concrete gave the highest compressive strength and abrasion resistance, whilst sandstone showed the lowest compressive strength and abrasion resistance.

Chen and Liu (2004) studied the effect of aggregate size distributions and the volume fraction of aggregate on the fracture parameters of concretes with strength $50-89 \mathrm{MPa}$ under three-point bending test. For this purpose three various maximum aggregate sizes of 10,15 and $20 \mathrm{~mm}$ were employed. They also investigated the influence of coarse aggregate volume fraction on the fracture parameters of HSC. For this purpose three various volume fraction of aggregates named $40 \%, 60 \%$ and $80 \%$ were employed. They concluded that HSC with lower brittles could be made by aggregate with greater size. The maximum fracture energy and fracture toughness were achieved at $60 \%$ of aggregate volume. On the other hand, Al-Oraimi et al. (2006) evaluated the effect of crushed limestone coarse aggregate size on the compressive strength of HSC. Two aggregate sizes (10 and $20 \mathrm{~mm}$ maximum size) were collected from five different areas. Cement was partially replaced with $10 \% \mathrm{SF}$, w/b ratio was 0.32 and superplasticizer was $12 \mathrm{l} / \mathrm{m}^{3}$. The 28 days compressive strength results varied between 81.3 $\mathrm{MPa}$ and $85.6 \mathrm{MPa}$ for the $10 \mathrm{~mm}$ maximum aggregate size, and ranged between $72.5 \mathrm{MPa}$ and $77.5 \mathrm{MPa}$ for $20 \mathrm{~mm}$ maximum aggregate size. They concluded that the use of smaller aggregate size gave higher strength.

The use of superplasticizer (HRWR) made it possible to produce a workable concrete with low w/b ratio, resulting in higher strength and better durability properties. However, lowering w/b ratio of concrete than a critical value may cause self-desiccation to occur, leading to autogenous shrinkage (Aitcin et al., 1977). The marked autogenous shrinkage in such systems can induce stress when the autogenous shrinkage is restrained, and may cause micro-cracks in the concrete if the stress exceeds the local tensile strength of the system (Aitcin et al., 1977; Paillere at al., 1989). Presently various types of pozzolanic materials, such as fly ash (FA), SF, rice husk ash, metakaolin (MK) and others have been widely used in concrete to obtain highperformance concrete principally aims at improving concrete microstructure. The pozzolanic materials have beside their pozzolanic effect a physical filling effect; hence the microstructure of hardened cement matrix becomes denser and stronger. However, some researches in literature can be summarizes as following: Haque (1996) prepared HSC with total cementitious contents of 550 and $600 \mathrm{~kg} / \mathrm{m}^{3}$. The concretes consisted of plain cement, $5 \%$ and $10 \%$ condensed SF and $10 \%$ condensed SF with $20 \%$ FA or slag. The highest compressive strength was obtained with the total cementitious contents of $550 \mathrm{~kg} / \mathrm{m}^{3}$ with $10 \%$ condensed SF.

Patnaik and Patnaikuni (2002) prepared HSC using cement content of $560 \mathrm{~kg} / \mathrm{m}^{3}$. The cement was partially replaced with $10 \% \mathrm{SF}$. The used w/b ratio was 0.23 with different dosages of superplasticizer. The results indicated that higher strength obtained with the proportion of SF. Mazloom et al. (2004) and Mazloom (2008) prepared HSC with fixed w/b ratio of 0.35 and a constant bender content of $500 \mathrm{~kg} / \mathrm{m}^{3}$. The cement was partially replaced with SF at levels of $0 \%, 6 \%, 8 \%, 10 \%$ and $15 \%$ with different dosages of superplasticizer to reach the same slump for all mixtures. The results indicated that $15 \% \mathrm{SF}$ gave the highest compressive 
strength. Erdem and Kirca (2008) employed different cement amounts of 500, 550, 600, 650 and $700 \mathrm{~kg} / \mathrm{m}^{3}$ to produce HSC. The cement was partially replaced with SF at replacement levels of $0 \%, 5 \%, 10 \%$ and $15 \%$. The mixtures were proportioned to have a constant consistency of slump $=6 \mathrm{~cm}$. The superplasticizer content was $3 \%$ for all the mixtures. For each employed amount of cement, the compressive strength results showed that the optimum cement replacement with SF was $15 \%$. Compressive strength of $72 \mathrm{MPa}$ was achieved at $425 \mathrm{~kg} / \mathrm{m}^{3}$ cement and $75 \mathrm{~kg} / \mathrm{m}^{3} \mathrm{SF}$, whilst $80.5 \mathrm{MPa}$ could be achieved at cement content $595 \mathrm{~kg} / \mathrm{m}^{3}$ and $105 \mathrm{~kg} / \mathrm{m}^{3} \mathrm{SF}$. Hariharan et al. (2011) carried out an experimental investigation to evaluate the compressive strength of HSC which made by partial replacement of cement with SF at levels of $0 \%, 6 \%$ and $10 \%$. The mixture proportions of concrete had a constant w/b ratio of 0.4 and various dosages of superplasticizer. The total binder content was $450 \mathrm{~kg} / \mathrm{cm}^{2}$. The compressive strength results showed that $6 \%$ SF gave the highest strength at ages of 3, 7, 28 and 90 days.

Regarding to HSC drying shrinkage, Gupta et al. (2009) evaluated the shrinkage of HSC made by partially replacement cement with either $10 \%$ SF or $10 \%$ FA. Also, different types of coarse aggregate (i.e. sandstone and granite) were studied. The results indicated that the shrinkage strain of concrete included either SF or FA at various ages was more (6 \% to $10 \%$ ) than the shrinkage strain of concrete with neat cement. The shrinkage strain of concrete with granite aggregate at 90 days was slightly less (6 \% to $7 \%$ ) than that of concrete with sandstone aggregate. Mazloom et al. (2004) studied drying shrinkage of HSC where cement was partially replaced with SF at replacement levels of $0 \%, 6 \%, 10 \%$ and $15 \%$ with different dosages of superplasticizer to reach the same slump for all mixtures. They reported that as the proportion of SF increased, as the autogenous shrinkage increased. Yang et al. (2005) investigated experimentally the autogenous shrinkage of HSC containing SF under drying at early ages. Three mixtures were prepared with w/b ratios of $0.25,0.35$ and 0.45 corresponding to binders (cement + SF) of $(576+64),(424+47)$ and $(340+38) \mathrm{kg} / \mathrm{m}^{3}$, respectively. They concluded that the earlier the drying initiation age and the higher the $\mathrm{w} / \mathrm{b}$ were the more significant the influence of drying initiation age was. Drying shrinkage became dominant as w/b increased. Haque (1996) prepared HSC with total cementitious contents of 550 and $600 \mathrm{~kg} / \mathrm{m}^{3}$. The concretes consisted of plain cement, $5 \%$ and $10 \%$ condensed SF and $10 \%$ condensed SF with $20 \%$ FA or slag. They reported that the addition of both $5 \%$ and $10 \%$ condensed SF in concretes resulted in a substantial reduction of drying shrinkage of the condensed SF concretes. Further addition of $20 \% \mathrm{FA}$ and slag increased the shrinkage.

The benefits of LS powder as a partial replacement for PC are well established. Economic and environmental advantages by reducing $\mathrm{CO}_{2}$ emissions are well known. The performance of LS filler addition to cement has been widely studied in pastes, mortars, and concretes (Gutteridge and Dalziel, 1990; Ye et al., 2007; Esping, 2008; Lee et al., 2008; Cam Hieu and Neithalath, 2010; Shuhua and Peiyu, 2010). In general, LS filler improves the hydration rate of cement compounds and consequently increases the strength at early ages (Gutteridge and Dalziel, 1990). From a chemical point of view, LS filler does not have pozzolanic properties, but it reacts with the alumina phases of cement to form an AFm phase (calcium monocarboaluminate hydrate) with no significant changes on the strength of blended cement (Bonavetti, 1998). The main effects of limestone filler are of physical nature. It causes a better packing of cement granular skeleton and a larger dispersion of cement grains (Opoczky, 1992). Furthermore, LS filler acts as the crystallization nucleus for the precipitation of $\mathrm{CH}$ (Soroka and Stern, 1977). These simultaneous effects produce an acceleration of the hydration of cement grains. A recent report (Caldarone and Zematjis, 2008) that investigated the use of $5 \%$ or less limestone powder interground with cement concluded that the fresh and hardened properties of 
mortars containing LS powder are comparable to or better than those of the companion plain mixtures. On the other hand, Ramezanianpour et al. (2009) studied the effect of various amounts of LS powder on compressive strength and rapid chloride permeability of NSC produced by using combination of cement and LS powder. Cement was partially replaced with LS powder at levels of $0 \%, 5 \%, 10 \%, 15 \%$ and $20 \%$. The results indicated that the compressive strength values decreased with the propagation of LS powder, but $10 \%$ LS powder provided competitive properties with cement. At 180 days, the chloride ions permeability of composite cement/LS concretes were higher than those of pure cement concrete.

There is no published literature on HSC containing LS without or with different amounts of $\mathrm{SF}$ and $\mathrm{MK}$ in the presence of different coarse aggregate types when moderate cement content was used. Workability, compressive strength, tensile strength, permeability and drying shrinkage were investigated. This investigation will therefore add valuable knowledge to the HSC system. In addition, this study aims to reduce the content of cement required to produce HSC. Thus, reducing $\mathrm{CO}_{2}$ emissions resulted by cement industry.

\section{Experimental program}

Four groups of concrete mixtures were proportioned to explore the possibility of producing HSC with moderate cement content. The effects of pozzolan type and dosage, and coarse aggregate type were investigated. SF was employed in the first two groups of mixtures and MK in the other two groups. As shown in Table 1, mixtures designation code consisted of five characters. The first letter is the coarse aggregate type, either dolomite (D) or basalt (B). The

Table 1. Investigated concrete mixtures

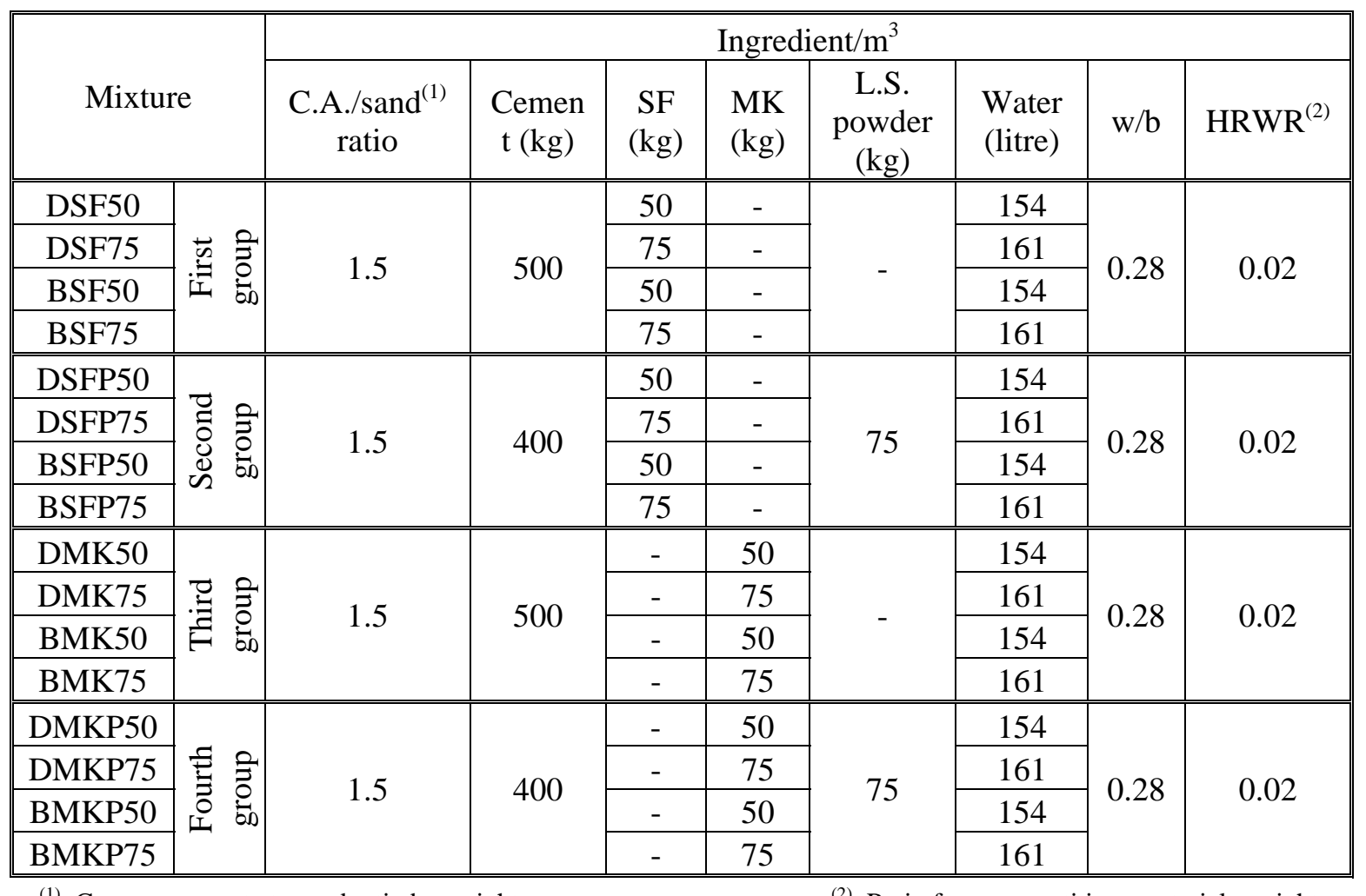

(1): Coarse aggregate to sand ratio by weight

${ }^{(2)}$ : Ratio from cementitious materials weight 
second and third letters stands for pozzolan type, either SF or MK. The fourth letter (if any) indicates lime stone powder, and the number (last character) refers to the content of pozzolan. For the sake of this investigation, the cement content is lowered from $500 \mathrm{~kg} / \mathrm{m}^{3}$ in the first and third groups to $400 \mathrm{~kg} / \mathrm{m}^{3}$ in the second and fourth groups, respectively. The difference in cement content is compensated by the addition of fine limestone powder with the same volume as cement replacement. Pozzolans were incorporated as an addition to cement in two fixed quantities either 50 or $75 \mathrm{~kg} / \mathrm{m}^{3}$ correspond, respectively, to $10 \%$ or $15 \%$ of the initial cement content (before limestone powder replacement).

\subsection{Materials used}

The coarse aggregates are crushed dolomite or crushed basalt with 8-mm nominal maximum size, and the fine aggregate is natural siliceous sand has a fineness modulus of 2.46 conforming to the medium grading zone of the Egyptian Standard specification ES 1109/2002 [15]. Fine materials are PC, LS, SF and MK. Portland cement (CEM I: 42.5 N) of Blaine surface area 3350 $\mathrm{cm}^{2} / \mathrm{g}$ conforming to the Egyptian Standard specifications ES 4756-1/ 2007 [16] was used. LS powder passing sieve no. 200 (75 microns). The SF used in the current investigation was obtained from disposal waste resulting from the ferro-silicon alloys industry i.e. from Egyptian Firro Alloys Company (EFACO) (in Cairo-Egypt). Its Blaine surface area and the specific gravity were $202000 \mathrm{~cm}^{2} / g$ and $2.32 \mathrm{t} / \mathrm{m}^{3}$, respectively. MK was produced by calcining kaolin at temperature of $850^{\circ} \mathrm{C}$ for $2 \mathrm{~h}$ (Rashad, 2009, 2011, 2013b, 2013c; Rashad et al., 2009; Morsy et al., 2008, 2009a, 2009b; Seleem et al., 2010, 2011). Figure 1 shows the diffractograms of SF and MK samples analyzed by X-ray diffraction (XRD). The chemical composition of the employed cement and pozzolans are given in Table 2. The employed superplasticizer (HRWR) is sulphonated naphthalene base with a specific gravity of $1.19-1.21 \mathrm{~kg} / \mathrm{l}, \mathrm{pH} 8-9$, solid content of $39.0-41.0 \%$, and conforming to Type F of ASTM C494 [4].

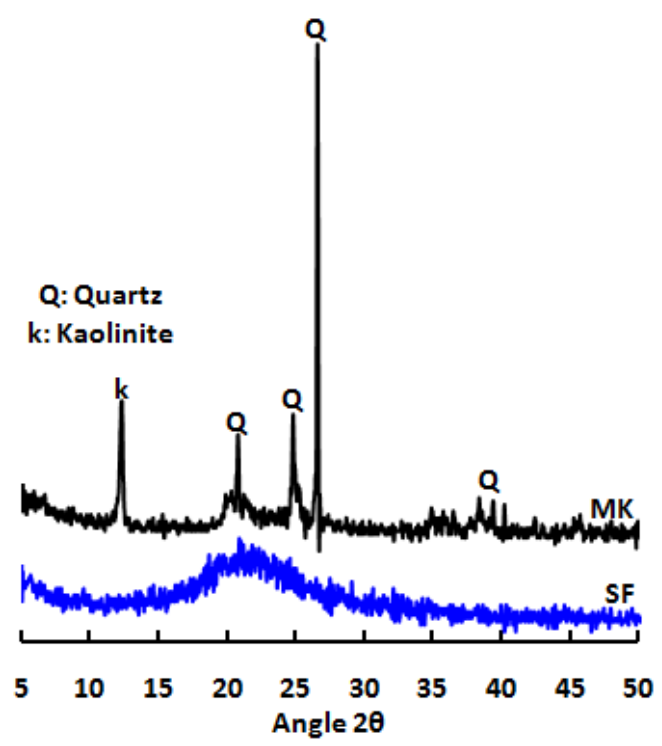

Figure 1. XRD pattern for SF and MK 
Table 2. Chemical composition of PC, SF and MK

\begin{tabular}{|c|c|c|c||}
\hline Oxide & $\begin{array}{c}\text { PC } \\
\text { (\% by weight) }\end{array}$ & $\begin{array}{c}\text { SF } \\
\text { (\% by weight) }\end{array}$ & $\begin{array}{c}\text { MK } \\
\text { (\% by weight) }\end{array}$ \\
\hline $\mathrm{SiO}_{2}$ & 20.39 & 94.5 & 58.52 \\
\hline $\mathrm{Al}_{2} \mathrm{O}_{3}$ & 5.6 & 1.03 & 35.54 \\
\hline $\mathrm{Fe}_{2} \mathrm{O}_{3}$ & 3.43 & 0.78 & 1.15 \\
\hline $\mathrm{CaO}$ & 63.07 & 1.1 & 1.24 \\
\hline $\mathrm{MgO}$ & 2.91 & 0.46 & 0.19 \\
\hline $\mathrm{Na}_{2} \mathrm{O}$ & 0.38 & 0.27 & 0.25 \\
\hline $\mathrm{K}_{2} \mathrm{O}$ & 0.35 & 0.43 & 0.05 \\
\hline $\mathrm{SO}_{3}$ & 0.7 & 0.08 & 0.06 \\
\hline $\mathrm{C}_{3} \mathrm{~A}$ & 9.04 & - & - \\
\hline L.O.I. & 2.06 & 1.31 & 2.74 \\
\hline
\end{tabular}

\subsection{Concretes composition and test methods}

Mixing operations of the concrete mixtures were sequenced as follows: sand was thoroughly mixed with cement, pozzolan, and LS powder (if any) in a pan mixer. About two thirds of the mixing water was added to the mixer and mixing operations continued until the mixture became homogeneous after about 90 seconds. Coarse aggregate was implemented to the wet mixture and mixing further continued for about 30 sec to assure complete homogeneity. The HRWR is premixed with the rest of water and was added to the rotating mixer and mixing operations further continued until the mixture became homogeneous after about 60 sec. Immediately after mixing workability in terms of slump was recorded. The oiled steel moulds of the different specimens were filled in approximately three equal layers and compacted manually. Curing was done by soaking in water until the age of testing. For each mixture shown in Table 1 , the following tests were conducted:

- Immediately after the concrete was charged from the mixer, fresh concrete test was performed according to ASTM C 143 [43].

- Compressive strength at three different ages; namely 7, 28, and 90 days. The compressive strength at each age is the average of testing three companion cubes with $150 \mathrm{~mm}$ side length.

- Splitting tensile strength at 28 days age using standard cylinders $150 \mathrm{~mm}$ diameter and 300 mm length. This test was performed according to ASTM C496 [5].

- Permeability at 28 days age; three half-cylinders, $150 \mathrm{~mm}$ diameter and $150 \mathrm{~mm}$ length, were prepared from each mixture. The outside cylindrical perimeters (lateral faces) of the specimens were painted with epoxy resin. The other two opposite faces were sanded to have clean surfaces. The specimens were positioned in the permeability cells of the testing apparatus, shown schematically in Figure 2. The water is forced to flow from one face to the other under 30 bar pressure continued for at least $24 \mathrm{~h}$. The permeated water is collected in a $100 \mathrm{ml}$ graduated flask. The formula for calculating the permeability coefficient (Darcy coefficient) is: 


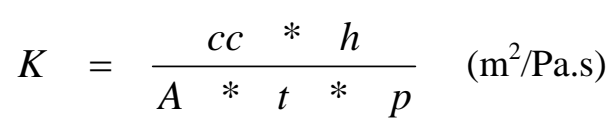

where:

$c c$ : permeated water $\left(\mathrm{m}^{3}\right), h$ : specimen height $(\mathrm{m}), A$ : specimen surface area $\left(\mathrm{m}^{2}\right), t$ : permeation time (seconds), $p$ : hydrostatic pressure $(\mathrm{Pa})$. However, the procedure to measure the permeability is similar to those previously reported in (Seleem et al., 2010).

- Drying shrinkage; free expansion test was performed on all the mixtures. The mortar fraction part of concrete mixtures was employed for casting mortar bars having overall dimensions of $25 \times 25 \times 285 \mathrm{~mm}$, in accordance with ASTM C157 [6]. Initial measurements were taken immediately after demolding the specimens. The specimens were cured in water until the age of 28 days, and then were left in lab conditions; relative humidity $50 \%$ and temperature $(20-25){ }^{\circ} \mathrm{C}$ for another 9 months. Length change measurements were monitored every other

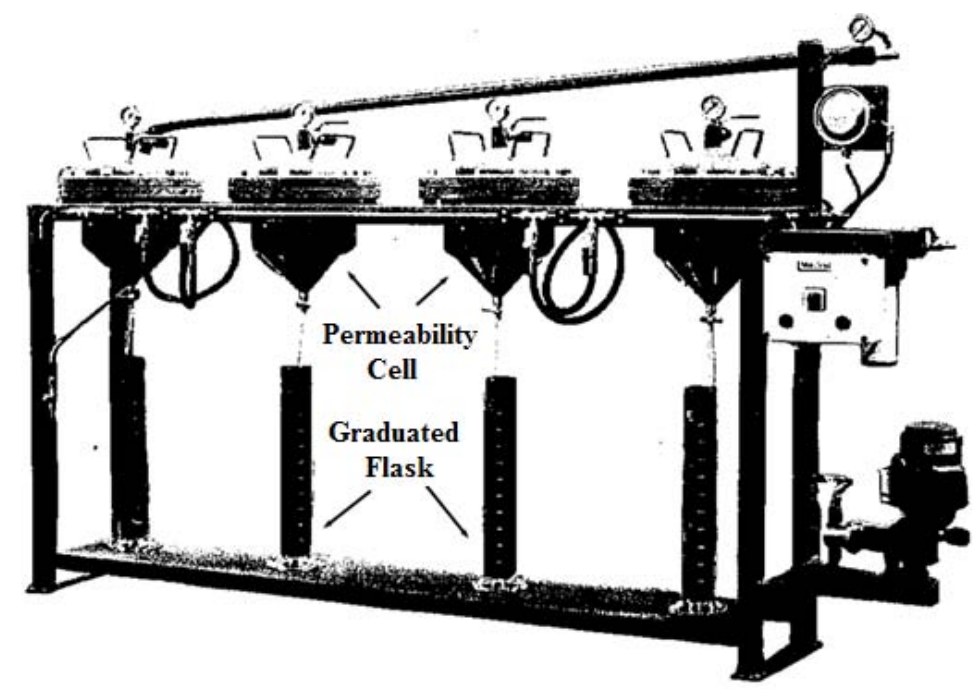

(a)

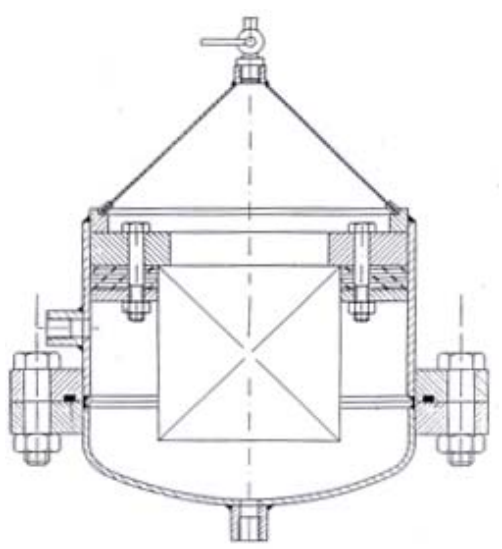

(b)

Figure 2. Water permeability apparatus (a) and permeability cell (b) 
day during the curing regime and the first month of lab storing, and every other week during the rest of testing period by means of a length comparator apparatus described in ASTM C490 [8].

- The used XRD apparatus, to perform the diffractograms of SF and MK samples that plotted in Figure 1, was of X'pert Pro type (Netherlands). The analysis was run at $40 \mathrm{kV}$ and $40 \mathrm{~mA}$ using $\mathrm{Cu} \mathrm{K \alpha}$ radiation and monochromatic filter. The $2 \theta$ ranged from $5^{\circ}-50^{\circ}$. The interpretation of the obtained phases was achieved by X'Port high score PDF-2 database software on CD-Release 2006.

\section{Results and discussion}

\subsection{Workability}

Figure 3 summarizes workability measurements in terms of slump values of the investigated concrete mixtures. The following main points are recognized:

- The slump values of the MK mixtures are exceedingly higher than those of the SF mixtures. Apparently, the ultra high fineness of SF with its known effect on viscosity increase impairs slump values.

- The type of coarse aggregate seems to have an effect on concrete workability; the slump in the case of basalt aggregate is higher than that for dolomite aggregate by ratios up to $14 \%$. Surface condition and aggregate porosity and consequently absorption capability are the main differences between the two kinds of aggregates thought to influence workability.

- Replacing part of the cement content with LS powder when maintaining the water content seems to have two distinct effects depending on the type of the employed pozzolan. In case of $\mathrm{SF}$, the slump values are more or less the same, little affected by the reduction in the cement content. This result could be attributed to the mixture relatively high viscosity implemented by SF. In case of MK, a pronounced enhancement in slump values up to $12 \%$ resulted from replacement part of cement with LS powder.

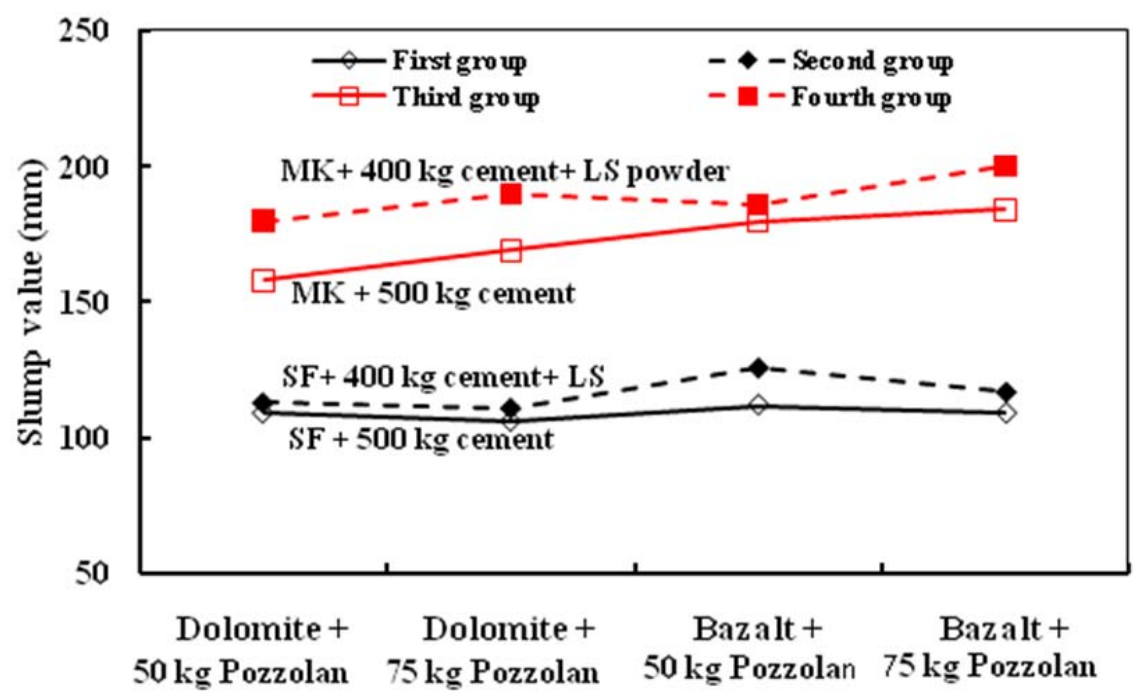

Figure 3. Slump values of the investigated concrete mixtures 


\subsection{Compressive strength results}

Figures 4 and 5 show the compressive strength development of the SF mixtures and the MK mixtures, respectively. It was generally noted that:

- The highest attained strength value is $82.4 \mathrm{MPa}$ at 90 days assigned for the mixture BSF75 with SF, $500 \mathrm{~kg}$ cement, and basalt aggregate. The second in order is $79.3 \mathrm{MPa}$ at the same age assigned to the corresponding mixture, BSFP75, with LS powder, SF, $400 \mathrm{~kg}$ cement, and basalt aggregate.

- Compressive strength of the SF mixtures is higher than those of the corresponding MK mixtures by ratios range from $26 \%$ to $30 \%, 27 \%$ to $40 \%$, and $10 \%$ to $14 \%$ at ages of 7,28 , and 90 days, respectively. Apparently, the strengths tend to converge with age increasing.

- Basalt aggregate is more prone to strength increase than dolomite aggregate. Unfortunately, no simple relation could be found to the impact of basalt aggregate in this regard.

- Replacing part of the cement content with LS powder caused two distinct effects depending on the type of the employed pozzolan. For SF mixtures, the strength reduction was initially significant at early ages and then diminishes with age increasing. Figure 4 shows that the reductions in compressive strength ranged from $20.4 \%$ to $12.8 \%, 10.1 \%$ to $3.5 \%$, and $6 \%$ to $1.9 \%$ at ages of 7,28 , and 90 days, respectively. For MK mixtures, the reduction in strength was significant at all ages and ranged from $20.8 \%$ to $13.8 \%, 12.5 \%$ to $9.6 \%$, and $17.8 \%$ to $15 \%$, at 7, 28, and 90 days age, respectively (Fig. 5).

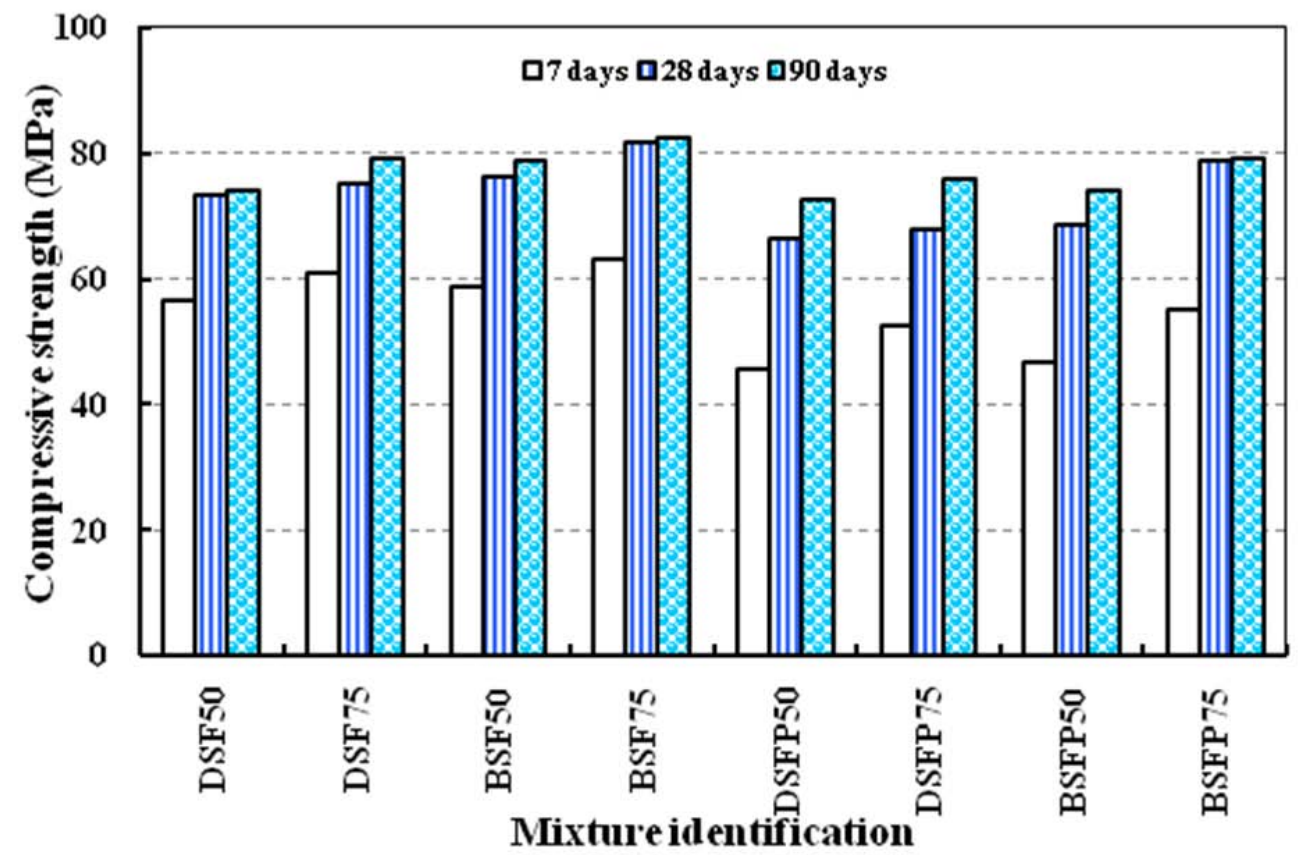

Figure 4. Compressive strength development of the SF mixtures 


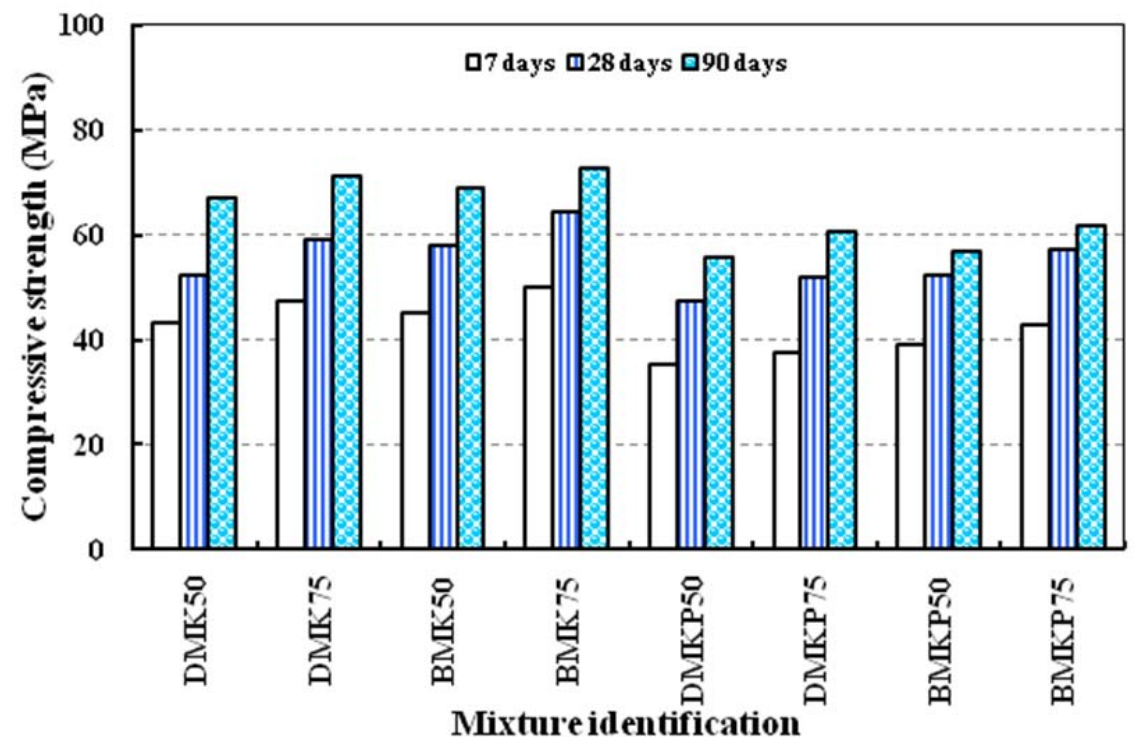

Figure 5. Compressive strength development of the MK mixtures

\subsection{Tensile strength}

The most commonly used test for estimating the tensile strength of concrete is the ASTM C496 splitting tension test. The tensile strength at 28 days age, shown in Figure 6, followed the compressive strength values at the same age. As could be seen, the tensile strength is rather sensitive to the type of pozzolan and coarse aggregate, and replacing some of the cement content with LS powder apparently resulted in a more or less constant reduction in strength about $5 \%$. It is interesting to note that the strength of the MK mixtures assumed nearly the same ratio, about $73 \%$, of that of the corresponding SF mixtures. However, these reductions are expected to decrease with increasing the age as found for compressive strength.

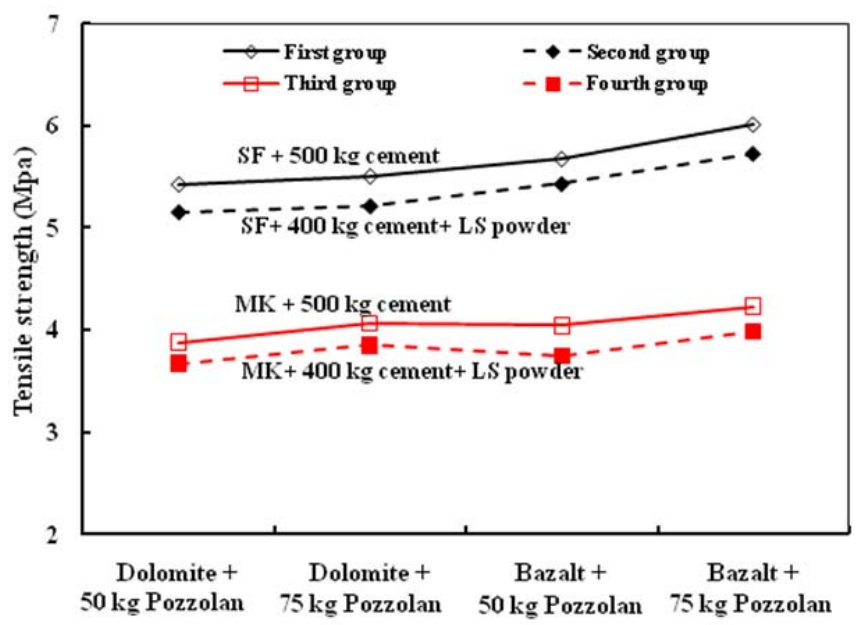

Figure 6. Splitting tensile strength of the investigated concrete mixture 


\subsection{Permeability}

Permeability measurements cited in Table 3 shows that all SF mixtures have comparable permeability coefficients regardless of the kind of coarse aggregate and the content of pozzolan. Furthermore, partially replacing cement with LS powder in these mixtures caused a slight increase in the permeability coefficient, not more than $10 \%$. Permeability coefficients of the MK mixtures are somewhat higher than those of the SF mixtures. That could be attributed to the ultra fineness and pozzolanic activity of SF which led to the formation of intense pozzolanic reaction products within the capillary pore spaces and in turn finer and more segmented pore system. The effect of partially replacing cement with LS powder in these mixtures is less apparent than the preceding case, as the maximum increase in permeability coefficient was about $6 \%$.

Table 3. Permeability of the investigated mixtures

\begin{tabular}{|c|c|c|c|c|c|}
\hline \multicolumn{2}{|c|}{ Mix designation } & $\begin{array}{c}\text { Permeability } \\
\mathrm{K}^{*} 10^{-16},\left(\mathrm{~m}^{2} / \text { Pa.s }\right)\end{array}$ & \multicolumn{2}{|c|}{ Mix designation } & $\begin{array}{c}\text { Permeability } \\
\mathrm{K}^{*} 10^{-16},\left(\mathrm{~m}^{2} / \text { Pa.s }\right)\end{array}$ \\
\hline DSF50 & \multirow{4}{*}{$\begin{array}{l}\text { First } \\
\text { group }\end{array}$} & 0.884 & DMK50 & \multirow{4}{*}{$\begin{array}{l}\text { Third } \\
\text { group }\end{array}$} & 1.16 \\
\hline DSF75 & & 0.86 & DMK75 & & 1.03 \\
\hline BSF50 & & 0.89 & BMK50 & & 1.12 \\
\hline BSF75 & & 0.85 & BMK75 & & 1.04 \\
\hline DSFP50 & \multirow{4}{*}{$\begin{array}{l}\text { Second } \\
\text { group }\end{array}$} & 0.96 & DMKP50 & \multirow{4}{*}{$\begin{array}{l}\text { Fourth } \\
\text { group }\end{array}$} & 1.22 \\
\hline DSFP75 & & 0.91 & DMKP75 & & 1.09 \\
\hline BSFP50 & & 0.98 & BMKР50 & & 1.19 \\
\hline BSFP75 & & 0.91 & BMKP75 & & 1.11 \\
\hline
\end{tabular}

\subsection{Drying shrinkage}

As known, shrinkage is the reduction in volume at constant temperature without external loading. It is as important material property that significant effects on long-term performance of designed structures. It also influences structural properties and durability of the material (Rashad, 2013a, 2013d, 2014) where drying shrinkage can be a major reason for deterioration of concrete structures. The contraction of the material is normally hindered by either internal or external restraints so that tensile stresses are induced. These stresses may exceed the tensile strength and cause concrete to crack. The one measured here represents the effect of drying and normally includes the autogenous one, and for practical purposes the former one need not be distinguished from the latter one.

Figures 7 and 8 show the linear strains upon wetting for 28 days then drying till another 9 months for the SF mixtures and the MK mixtures, respectively. All mixtures exhibited the same trend although the deformation strains were not so. For SF mixtures, both swelling and drying shrinkage are governed by the SF content. Meanwhile, replacing some of the cement content with LS powder caused a reduction in both kinds of strains. The reductions were up to $30 \%$ swelling strains and up to $20 \%$ shrinkage strains. These reductions are generated from lowering cement content with a relatively stable compound, i.e. LS powder. On the other hand, the deformation strains of the MK mixtures are generally governed by the cement content, little 
affected by the pozzolan content. Figure 8 shows that partial replacement of cement with LS powder efficiently reduced both kinds of strains; up to $30 \%$ swelling and up to $15 \%$ shrinkage.

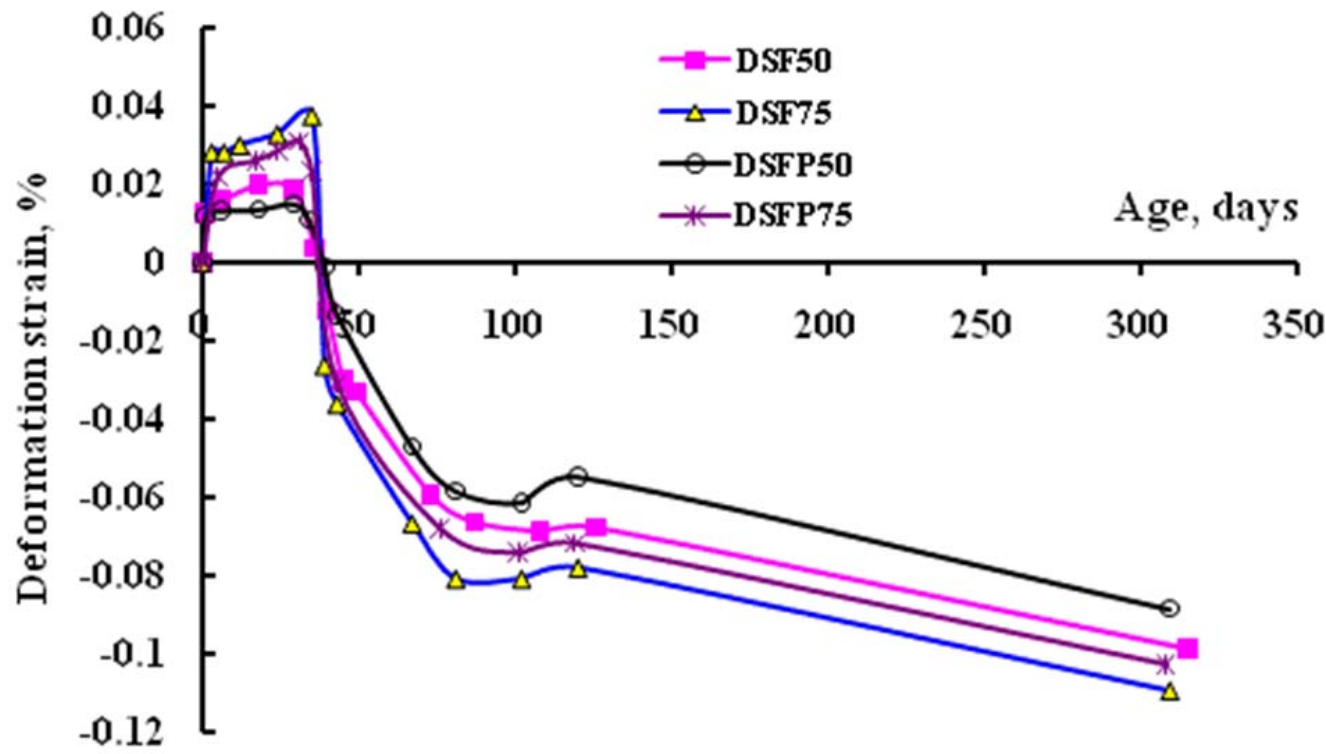

Figure 7. Deformation strains of the SF mixtures

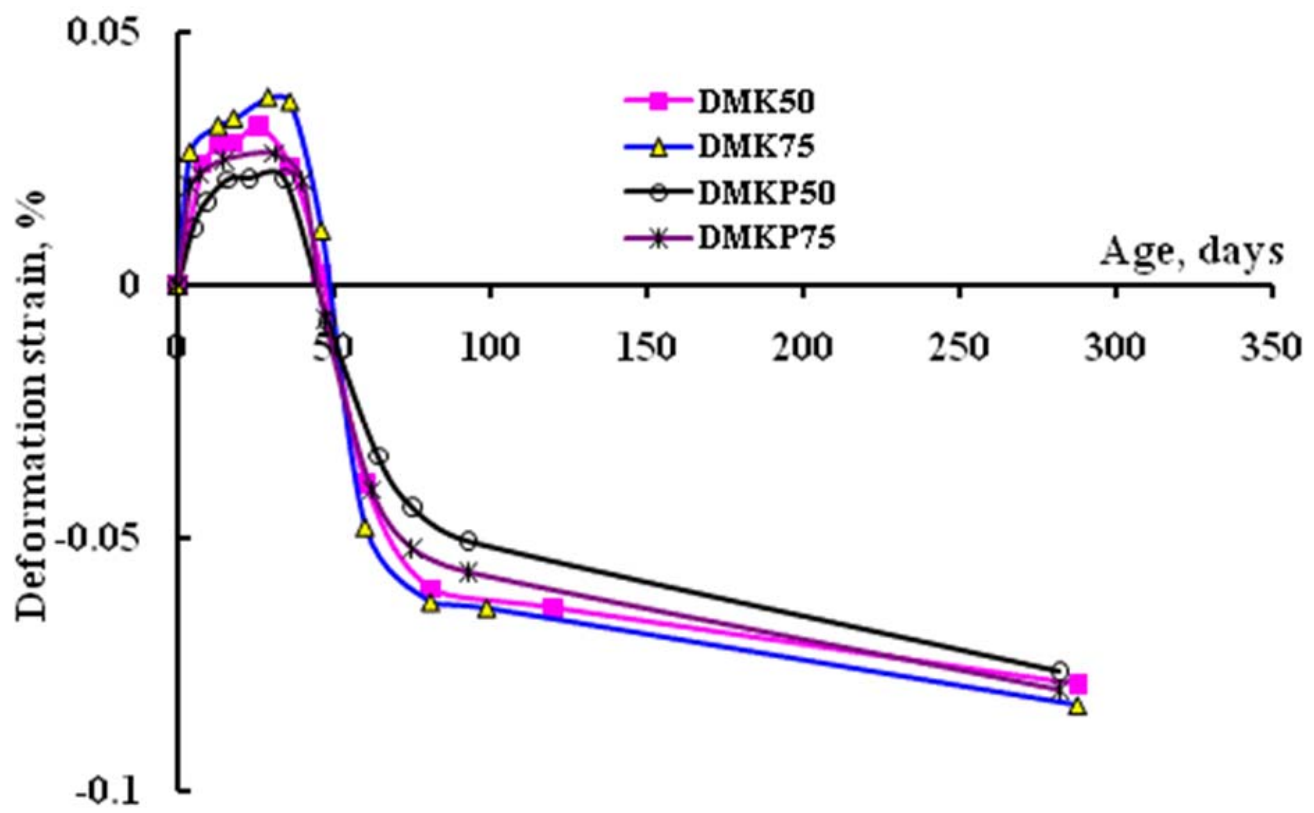

Figure 8. Deformation strains of the MK mixtures 


\section{Conclusions}

The objective of the present work is to explore the possibility of producing HSC with an economic rate for cement consumption while giving as close as possible the desired properties. The reduction in cement consumption is believed to reduce the cost, and give a rational solution to some concrete disadvantages like cracking due to thermal changes and drying. From the results achieved for the workability, compressive strength, tensile strength, permeability, and drying shrinkage tests the following conclusions are drawn:

1. In terms of consistency, higher slump values could be obtained by employing MK rather than $\mathrm{SF}$, basalt coarse aggregate rather than dolomite, and by partially replacing cement with LS powder.

2. It was possible to produce concrete with a compressive strength of an order of 79.3 MPa with cement consumption $400 \mathrm{~kg} / \mathrm{m}^{3}$. High packing density of fine grains in the binder matrix, limited aggregate size, relatively low water-to-binder ratio, and a relatively high dose of HRWR are the main keys for HSC with moderate cement content.

3. SF and basalt aggregates are more prone to strength increase than MK and dolomite aggregates, respectively. While strength increases in proportion to SF content, no simple relation could be found to the impact of basalt aggregates in this regard.

4. Partially replacing cement with LS powder caused two distinct effects on strength depending on the type of the employed pozzolan. For SF mixtures, the strength reductions were initially significant at early age but later on with age increasing the reductions diminish. For MK mixtures, the reductions in strength were significant at all ages.

5. The tensile strength trends generally followed compressive strength at the same age. Replacing some of the cement content with LS powder apparently resulted in a more or less a constant reduction in tensile strength about $5 \%$.

6. Permeability measurements show that all SF mixtures have comparable permeability coefficients regardless of the kind of coarse aggregate and the content of pozzolan. Furthermore, partially replacing cement with LS powder in these mixtures caused a slight increase in permeability coefficient, not more than $10 \%$.

7. Permeability coefficients of the MK mixtures are somewhat higher than those of the SF mixtures. Partially replacing cement with LS powder in these mixtures is less apparent than for SF mixtures, as the maximum increase in permeability coefficient was about $6 \%$.

8. Linear strains upon wetting for 28 days (swelling) then drying till another 9 months (shrinkage) for the SF mixtures and the MK mixtures are generally reduced due to employing LS powder as a partial replacement of cement.

\section{REFERENCES}

[1] ACI Committee 363 (2001), "State-of-the art report on high strength concrete”, ACI manual of concrete practice: Part 1. Farmington Hills (MI): ACI.

[2] Aitcin, P. C., Neville, A. M. and Acher, P. (1977), "Integrated view of shrinkage deformation”, Concr. Int. 19, 35-41.

[3] Al-Oraimi, S. K., Taha, R. and Hassan, H. F. (2006), “The effect of the mineralogy of coarse aggregate on the mechanical properties of high-strength concrete”, Construction and Building materials 20, 499-503.

[4] American Society for Testing and Materials (1992), "Standard specifications for chemical admixtures for concrete”, ASTM C494-92, Philadelphia. 
[5] American Society for Testing and Materials (2002), "Standard test method for splitting tensile strength of cylindrical concrete specimens”, ASTM C496-02, Annual Book ASTM Standards, 4 (04.02).

[6] American Society for Testing and Materials (2008), "Standard test method for length change of hardened hydraulic-cement mortar and concrete”, ASTM C157/C157M-08.

[7] American Society for Testing and Materials (2010), "Standard test method for slump of hydraulic cement concrete”, ASTM C143/C143M-10a.

[8] American Society for Testing and Materials (2011), "Standard practice for use of apparatus for the determination of length change of hardened cement paste, mortar, and concrete", ASTM C490/C490M-11.

[9] Beshr, H., Almusallam, A. A. and Maslehuddin, M. (2003), "Effect of coarse aggregate quality on the mechanical properties of high strength concrete", Construction and Building Materials 17, 97-103.

[10] Bonavetti, V. (1998), Cementos con filler calcáreo - Mecanismo de interacción y su influencia sobre las propiedades resistentes, MSc thesis, University of Center Buenos Aires State, Argentine, 242.

[11] Caldarone, M. A. and Zematjis, J. Z. (2008), "Effect of use of limestone on various properties of Portland cement - Part II”, PCA R \& D SN 289 la. Skokie (IL): Portland Cement Association, 27.

[12] Cam Hieu, T. and Neithalath, N (2010), "Moisture and ionic transport in concretes containing coarse limestone powder", Cement \& Concrete Composites 12, 486-496.

[13] Chang, T. P. and Su, N. K. (1996). "Estimation of coarse aggregate strength in HSC", ACI Materials Journal 93, 3-8.

[14] Chen, B. and Liu, J. (2004), "Effect of aggregate on the fracture behavior of high strength concrete", Construction and Building Materials 18, 585-590.

[15] Egyptian Standard Specifications (2002) Concrete aggregate from natural resources, ES: 1109/2002.

[16] Egyptian Standard Specifications (2007), Composition, specifications and conformity criteria for common cements, Part 1, ES 4756-1/2007.

[17] Erdem, T. K. and Kırca, Ö. (2008), "Use of binary and ternary blends in high strength concrete”, Construction and Building Materials 22, 1477-1483.

[18] Esping, O. (2008), "Effect of limestone filler BET (H2O) - area on the fresh and hardened properties of self-compacting concrete", Cement and Concrete Research 38, 938-44.

[19] Glaccio, G. and Zerbino, R. (1998), "Failure mechanism of concrete: combined effects of coarse aggregate and strength level”, Advanced Cement Based Materials 7, 41-48.

[20] Gupta, S. M., Sehgal, V. K. and Kaushik, S. K. (2009), "Shrinkage of high strength concrete”, Proceedings of World Academy of Science, Engineering and Technology, 38, 268-271.

[21] Gutteridge, W. and Dalziel, J. (1990), "Filler cement: The effect of the secondary component on the hydration of Portland cement: Part 1. A fine non-hydraulic filler", Cement and Concrete Research 20, 778-782.

[22] Haque, M. N. (1996), "Strength development and drying shrinkage of high-strength concretes”, Cement and concrete Composites 18, 333-342. 
[23] Hariharan, A. R., Santhi, A. S. and Ganesh, G. M. (2011), "Study on strength development of high strength concrete containing fly ash and silica fume”, International Journal of Engineering Science and Technology (IJEST) 3, 2955-2961.

[24] Kılıç, A., Atiş, C. D., Teymen, A., Karahan, O., Özcan, F., Bilim, C. and Özdemir, M. (2008), "The influence of aggregate type on the strength and abrasion resistance of high strength concrete”, Cement \& Concrete Composites 30, 290-296.

[25] Kmita, A. (2000), “A new generation of concrete in civil engineering”, Journal of Materials Processing Technology 106, 80-86.

[26] Lee, S. T., Hooton, R. D., Jung, H. S., Park, D. H. and Choi, C. S. (2008), "Effect of limestone filler on the deterioration of mortars and pastes exposed to sulfate solutions at ambient temperature”, Cement and Concrete Research 38, 68-76.

[27] Mazloom, M., Ramezanianpour, A. A. and Brooks, J. J. (2004), "Effect of silica fume on mechanical properties of high-strength concrete”, Cement \& Concrete Composites 26, 347-357.

[28] Mazloom, M. (2008), „Estimating long-term creep and shrinkage of high-strength concrete”, Cement \& Concrete Composites 30, 316-326.

[29] Morsy, M. S., Rashad, A. M. and Shebl, S. S. (2008), "Effect of elevated temperature on compressive strength of blended cement mortar”, Building Research Journal 56, 173-185.

[30] Morsy, M. S., Shebl, S. S. and Rashad, A. M. (2009a), "Effect of fire on microstructure and mechanical properties of blended cement pastes containing metakaolin and silica fume”, Sili. Indus. 74, 59-64.

[31] Morsy, M. S., Rashad, A. M. and El-Nouhy, H. A. (2009b), "Effect of elevated temperature on physico-mechanical properties of metakaolin blended cement mortar”, Structural Engineering and Mechanics 31, 1-10.

[32] Opoczky, L. (1992), "Progress of the particle size distribution during the intergrading of a clinker-limestone mixture”, Zem.-Kalk-Gips 45, 648-651.

[33] Paillere, A. M., Buil, M. and Serrano, J. J. (1989), "Effect of fiber addition on the autogenous shrinkage of silica fume concrete”, ACI Materials Journal 86, 139-144.

[34] Patnaik, A. K. and Patnaikuni I. (2002), "Correlation of strength of $75 \mathrm{~mm}$ diameter and $100 \mathrm{~mm}$ diameter cylinders for high strength concrete”, Cement and Concrete Research 32, 607-613.

[35] Ramezanianpour, A. A., Ghiasvand, E., Nickseresht, I., Mahdikhani, M. and Moodi, F. (2009), "Influence of various amounts of limestone powder on performance of Portland limestone cement concretes”, Cement \& Concrete Composites 31, 715-720.

[36] Rashad, A. M., Seleem Hosan El-Din, H. and Yousry Khalid, M. (2009a), "Compressive strength of concrete mixtures with binary and ternary cement blendes”, Building Research Journal 57, 107-130.

[37] Rashad, A. M. (2009b), "Effect of incorporating blended cement on fresh and hardened properties of concrete”, Sil. Ind. 74, 245-254.

[38] Rashad, A. M. (2011), “Chloride ion permeability of plain and blended cement concretes”, Building research Journal 59, 39-51. 
[39] Rashad, A. M. (2013a), “A comprehensive overview about the influence of different additives on the properties of alkali-activated slag - A guide for Civil Engineer”, Construction and Building Materials 47, 29-55.

[40] Rashad, A. M. (2013b), "Metakaolin as cementitious material: History, scours, production and composition - A comprehensive overview”, Construction and Building Materials 41, 303-318.

[41] Rashad, A. M. (2013c), “A preliminary study on the effect of fine aggregate replacement with metakaolin on strength and abrasion resistance of concrete”, Construction and Building Materials 44, 487-495.

[42] Rashad, A. M. (2013d), "Properties of alkali-activated fly ash concrete blended with slag”, Iranian Journal of Materials Science \& Engineering 10, 57-64.

[43] Rashad, A. M. (2014), “A comprehensive overview about the influence of different admixtures and additives on the properties of alkali-activated fly ash”, Materials and Design 53, 1005-1025.

[44] Seleem H. El_Din, Rashad Alaa M. and El-Sabbagh Basil A. (2010), "Durability and strength evaluation of high-performance concrete in marine structures”, Construction and building Materials 24, 878-884.

[45] Seleem, H. El-Din, Rashad, A. M. and Elsokary, T. (2011), "Effect of elevated temperature on physico-mechanical properties of blended cement concrete”, Construction and building Materials 25, 1009-1017.

[46] Shuhua, L. and Peiyu, Y. (2010), "Effect of limestone powder on microstructure of concrete”, Journal of Wuhan University of Technology-Mater., Sci. Ed. 25, 328-331.

[47] Soroka, I. and Stern, N. (1977), “The effect of fillers on strength of cement mortars”, Cement and Concrete Research 7, 449-456.

[48] Yang, Y. Sato, R. and Kawai, K. (2005), “Autogenous shrinkage of high-strength concrete containing silica fume under drying at early ages”, Cement and Concrete Research 35, 449-456.

[49] Ye. G., Liu, X., De Schutter, G., Poppe, A.-M. and Taerwe, L. (2007), "Influence of limestone powder used as filler in SCC on hydration and microstructure of cement pastes", Cement \& Concrete Composites 29, 94-102. 